DOI https://doi.org/10.18551/rjoas.2020-10.12

\title{
GILL HISTOPATHOLOGICAL ANALYSIS OF TILAPIA IN WANGI RIVER WATERS
}

\author{
Mardika Hanisya Putri Kania*, Herawati Endang Yuli, Zakiyah Umi \\ Faculty of Fisheries and Marine Sciences, University of Brawijaya, Indonesia
}

Putra Joni Johanda

Faculty of Fisheries and Marine Sciences, University of Jenderal Soedirman, Indonesia

\author{
*E-mail: humas@ub.ac.id
}

\begin{abstract}
Wangi River has complex waters as they are affected by industrial waste and human activities. The river is in the Beji sub-district, Pasuruan Regency, East Java. The water quality in several urban rivers has deteriorated due to heavy metal pollution. Fish, as one of the river's biota, is also directly affected. Histopathological changes can help identify the pollution severity. This study aimed to examine the histopathology of tilapia gills exposed to $\mathrm{Hg}, \mathrm{Pb}, \mathrm{Cd}$ metals in the Fragrant River's waters. The results found hyperplasia, hemorrhage, and edema in tilapia from 2 stations.
\end{abstract}

\section{KEY WORDS}

Histopathology, Oreochromis sp., Wangi River.

Increased human activities on the land mean heightened risks of pollution in the river. According to Wartabromo (2015), several factories took part in polluting the Wangi River waters in the Beji sub-district, Pasuruan Regency, East Java. Following pollution, the aquatic environment's quality will decrease, affecting the biota in it. It is suspected that heavy metal content in the river has accumulated. According to preliminary research test results, the following heavy metals were detected: lead $(\mathrm{Pb})$, mercury $(\mathrm{Hg})$, and cadmium $(\mathrm{Cd})$. It was found that lead $(\mathrm{Pb})$ had the highest level among other metals in the waters $(0.020-0.035$ $\mathrm{mg} / \mathrm{L}$ ), while in the sediment, the $\mathrm{Pb}$ level was $0.320-0.524 \mathrm{mg} / \mathrm{L}$. It indicates that the $\mathrm{Pb}$ level has reached over the permissible threshold, which is $0.03 \mathrm{mg} / \mathrm{L}$, according to Government Regulation No 82 of 2001. In addition, there was a petition addressed to the Pasuruan Regent and stakeholders; it led to a suspicion that there was pollution in the Wangi River. People were concerned that the pollution would disturb the balance of the environment, including the river's biota.

Fish is a biota sensitive to pollution. The fish found in the Wangi River are Tilapia (Oreochromis sp). According to Nirmala (2012), fish with the genus Oreochromis $s p$ is the biota recommended by the USEPA (US Environmental Protection Agency) for toxicological testing. It is used as biomonitoring of fish health level, detected from the gills' histopathological profile. Changes in fish organ tissue can also be used as a benchmark for the presence of accumulated heavy metals. Fish histopathological evaluation is a monitoring tool to describe the effects of environmental stress on fish. It also shows that one of the most reliable indicators of aquatic biota's health is anthropogenic activity. Mohamed (2008) found $\mathrm{Fe}, \mathrm{Zn}, \mathrm{Cu}, \mathrm{Pb}, \mathrm{Cd}$, and $\mathrm{Co}$ in the liver, gills, digestive tract, testes, liver, and Oreochromis niloticus and Lates niloticus fish muscles. The gills can experience edema followed by the desquamation of secondary lamellar epithelium, as suggested in the study of Rennika et al. (2013), and epithelial cell necrose, which results in death. As stated by Jasim et al. (2016), damage to the secondary lamellae fusion caused mucus secretion to protect and reduce toxic substances, which caused shortness of breath and death, from entering the fish body.

This study aimed to examine the histopathology of tilapia gills exposed to $\mathrm{Hg}, \mathrm{Pb}$, and Cd in the Wangi River waters. 


\section{METHODS OF RESEARCH}

In this study, the histopathological testing sample was the gill organs of tilapia (Oreochromis sp). Gill and liver samples were taken from 2 stations. A control sample was also needed. Tilapia (Oreochromis sp) was conditioned in an aquarium and used as a control or comparison sample. The preparation of histological preparations consisted of three stages: (1) tissue fixation and paraffin block, (2) tissue cutting, and (3) tissue staining. Gill histopathology also used damage scoring analysis. The scoring was carried out to determine the percentage level of damage to tilapia's gill tissue due to exposure to Wangi River water suspected to contain heavy metals $\mathrm{Hg}, \mathrm{Pb}$, and $\mathrm{Cd}$. The percentage of damage per field of view was calculated based on the number of damaged cells. The scoring was done according to Raza'l (2008): 1-4; in which ' 1 ' was for $0-5 \%$ damage, ' 2 ' was for $6-25 \%$ damage, ' 3 ' was for $26-50 \%$ damage, and ' 4 ' was for more than $50 \%$ damage. This study used a descriptive-writing method and comparative literature.

\section{RESULTS AND DISCUSSION}

The river was suspected to contain heavy metals such as $\mathrm{Hg}, \mathrm{Pb}$, and $\mathrm{Cd}$. The study results found tilapia gills damage, as shown in Table 1.

Table 1 - The Scoring Results of Damage Percentage Level

\begin{tabular}{|c|cccccccc|}
\hline \multirow{2}{*}{ Location } & Damage & \multicolumn{9}{c}{ Field of View Score } & \multirow{2}{*}{ average } & STD \\
\cline { 2 - 7 } & & 1 & 2 & 3 & 4 & 5 & & 0.55 \\
\multirow{2}{*}{ Station 1 } & Hyperplasia & 3 & 4 & 4 & 4 & 3 & 3.60 & 0.89 \\
& Hemorrhage & 3 & 2 & 2 & 4 & 2 & 2.60 & 0.55 \\
\multirow{2}{*}{ Station 2 } & Hemorrhage & 4 & 4 & 3 & 4 & 3 & 3.60 & 0.84 \\
& Edema & 4 & 2 & 3 & 3 & 4 & 3.20 & 0.20 \\
\hline
\end{tabular}

Table 1 shows that hyperplasia and hemorrhage are found in station 1, while hemorrhage and edema are found in station 2. Based on the research results, the description of tilapia gills exposed to Wangi River waters in stations 1 and 2 is as follows:

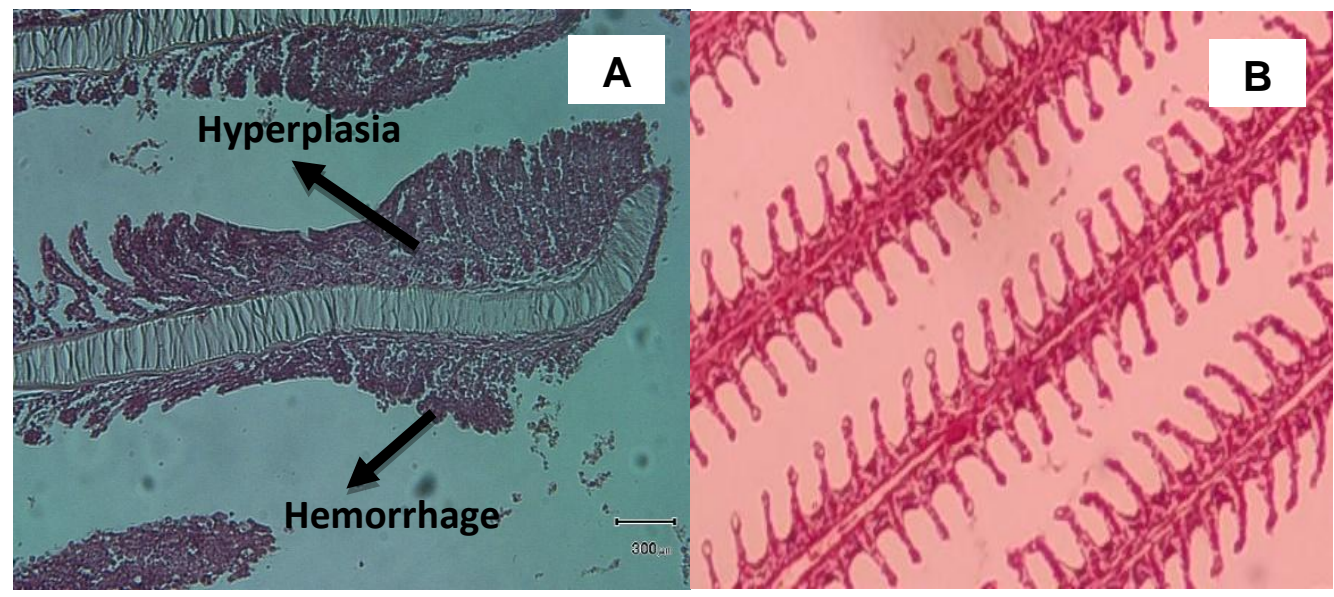

Figure 1-(A) Gill histology of fish gills at Station 1, magnification of 400x, (B) Gill histology of control tilapia

Hyperplasia is the most common histopathological change in gills. Fish samples taken had secondary lamellar hyperplasia and was followed by inflammation in tilapia at station 1 . The score for damage to hyperplasia at station 1 was 3.60, which means that the gills had severe hyperplasia. It proves that there have been pollutants in the waters affecting the structure of the gill tissue. Secondary lamellar hyperplasia can range from mild to severe. Severe secondary lamellar hyperplasia occurs when nearly all secondary gill lamellae are 
thickened. Mild secondary lamellar hyperplasia occurs only when a small portion of the secondary gill lamellae is thickened.

Secondary lamellar hyperplasia is caused by the habitat of tilapia that can live in waters with low quality. According to Camargo and Martinez (2007), water contamination by human activities such as agriculture and industry, which contains various organic and inorganic pollutants including oil, heavy metals, pesticides, and fertilizers, changes the water quality and causes fish health problems. Histopathological changes of fish gills exposed to pollutants are epithelial cell hyperplasia and lifting of gill lamellar epithelium. According to Roberts (2001), lamellar hyperplasia is usually associated with increased numbers and migration of Malpighian cells in the primary lamella. Secondary lamellar hyperplasia is also associated with edema of the lamella, hypertrophy of epithelial cells, and pillar cells' shape changes. However, the main factor is an increase in the number of chloride cells that extends to the secondary lamella surface, resulting in the thickening of the secondary lamella. The result of the secondary thickening of the lamellae in the respiratory area is reduced. There is also disruption of ion exchange in the epithelium and chloride cells' normal function.

The scoring result for hemorrhage damage at station 1 was 2.60 , meaning that the gills were severely damaged. It is indicated by erythrocytes that left the blood vessels and were in the gill tissue. When compared with the control sample, the gills at station 1 had very different tissue structures. According to Darmono (1995), damage to fish tissue is categorized into three levels: mild (fatty liver, characterized by cell swelling), moderate (congestion and hemorrhage), and severe (characterized by necrosis). Azis et al. (2018) found that broom fish affected by $\mathrm{Cr}$ metal waste from the leather tanning metal industry had hemorrhage. It indicates that the location of station 1 is near an industrial area.

Station 2 found that hemorrhage and edema were the most dominant damages. Figure 2 presents gill damage at station 2 as follows:

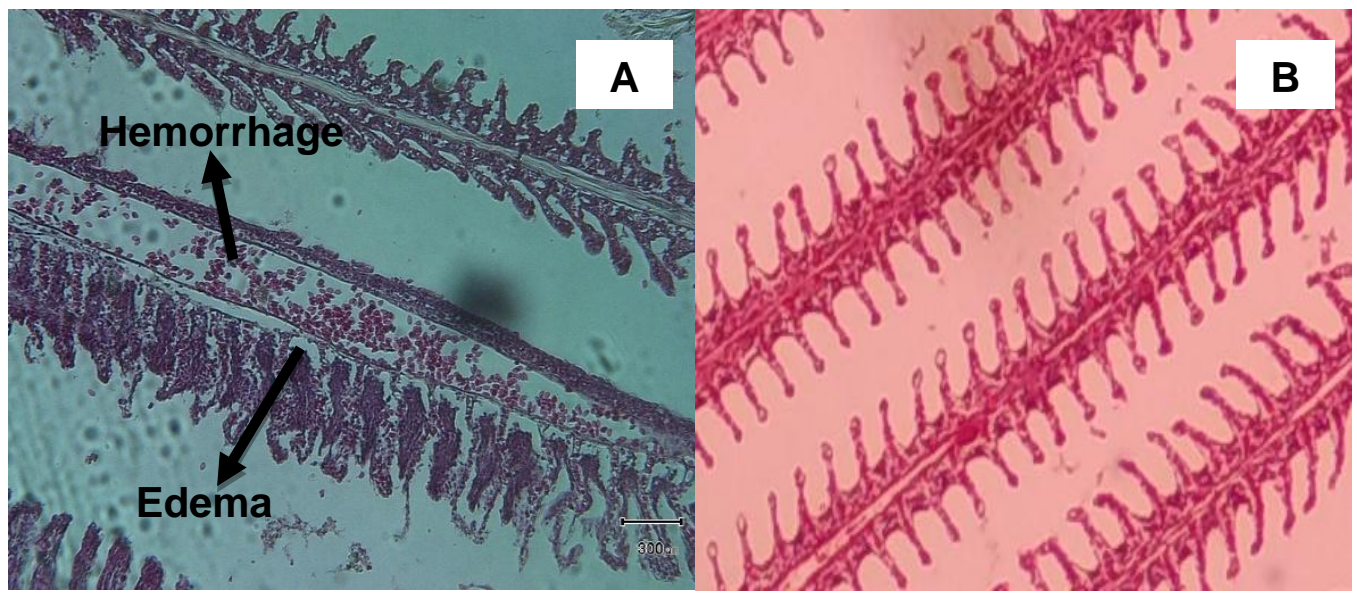

Figure 2 - (A) Gill histology at station 2 with 100x magnification,

(B) Gill histology of control tilapia

Edema damage scoring was found in tilapia gills at station 2, caused by chemicals such as pesticides and heavy metals. The score was around 3.20, meaning that the gills at station 2 had severe edema. It was also related to the habitat of tilapia that can survive in dirty water. However, it was also caused by household waste discarded directly into the Wangi River. The waste, such as excessive excretion of ammonia in the form of NH3, resulted in increased vascular permeability and was toxic for fish. According to Roberts (2001), edema in the lamellae was caused by exposure to chemical pollution, including metals, pesticides, formalin, or hydrogen peroxide, at an extremely high dose. It can also be caused by acute nutritional aflatoxicosis leading to severe edema in the lamella. After edema, it continued with the respiratory epithelium's desquamation in the primary and secondary lamella with significant necrosis of lamellar epithelial cells, often lethal due to difficulty breathing osmoregulation. Amalia et al. (2016) thought that edema was caused by 
Cd metal presence, exposing the gills and caused a decrease in ATP activity in the carbonic anhydrase and ATPase enzymes. It led to the collapse of the sodium pump in sensitive membranes. It contributed to intracellular sodium influx and extracellular diffusion of potassium and water iso-osmosis failure leading to gill inflammation. It is in line with the location of station 2, which is between industrial, residential, and agricultural areas.

The scoring result for hemorrhage damage at station 2 was 3.60, meaning that the tilapia gills at station 2 were severely damaged. According to Amalia et al. (2016), if the hydrostatic pressure and intravascular osmotic pressure in the gill capillaries continues to increase due to $\mathrm{Cd}$, it will damage and tore the integrity of the gill capillaries, causing blood and fluid to come out; this is called hemorrhage.

\section{CONCLUSION}

Tilapia found in the Wangi River waters have been exposed to metals as the fish tissue damage like hemorrhage, hyperplasia, and edema are found. Therefore, it can be said that the waters of the Wangi River have been contaminated with pollutant waste materials.

\section{REFERENCES}

1. Amalia,W.R., B.Halang, A.Naparin. 2016. Kandungan Kadmium(Cd) Pada Air, Daging serta Mikroanatomi Insang Ikan Kelabau (Osteochillus melanopleurus) di Muara Sungai Martapura.Prosiding Seminar Nasional Tahun 2016. IPB Bogor. 84-92.

2. Azis, M.U., T.Herawati, Z.Anna, and I.Nurruhwati. 2018. Pengaruh Logam Kromium (Cr) Terhadap Histopatologi Organ Insang, Hati and Daging Ikan di Sungai Cimanuk Bagian Hulu Kabupaten Garut. Jurnal Perikanan and Kelautan.9(1): 119-128.

3. Camargo, M. M. P. and C. B. R. Martinez. 2007. Histopathology of Gills, Kidney and Liver of a neutrofical fish caged in an urban stream. Journal Neotropical Ichtiology. 5(3): 327336.

4. Darmono. 1995. Logam Dalam Sistem Biologi Makhluk Hidup. UI Press. Jakarta.

5. Jasim, M.A., M. Sofian, Yusoff, and M.M. Rahman. 2016. Bioaccumulation and Histopathological Changes induced by Toxicity of Mercury to Tilapia Fish Oreochromis niloticus. Sains Malaysiana. 45 (1): 119-127.

6. Mohamed, F.A.S . 2008. Bioaccumulation of Selected Metals and Histopathological Alterations in Tissues of Oreochromis niloticus and Lates niloticus from Lake Nasser, Egypt. Global Veterinaria . $4: 205-218$.

7. Nirmala, K., Y.P. Hastuti, and V. Yuniar. 2012. Toksisitas Merkuri (Hg) and Tingkat Kelangsungan Hidup, Pertumbuhan, Gambaran Darah, and Kerusakan Organ Pada Ikan Nila Oreochromis niloticus. Jurnal Akuakultur Indonesia. 11 (1) : 38-48.

8. Peraturan Pemerintah Nomor 82 tahun 2001 tentang Pengelolaan Kualitas Air and Pengendalian Pencemaran Air.

9. Raza'i, R. S., 2008. Analisis Histopatologi Organ Insang and Usus Ikan Kerapu (Epinephelus coloides) Yang Diberikan Khamir laut (Marine yeast) Sebagai Imunostimulan.Tesis. Minat Bioteknologi Perikanan and Kelautan Jurusan Budidaya Perairan Program Pascasarjana Fakultas Perikanan and IImu Kelautan, universitas Brawijaya, Malang.

10. Rennika,. Aunurohim, and N.Abdul Gani. 2013. Konsentrasi and Lama Pemaparan Senyawa Organik and Inorganik pada Jaringan Insang Ikan Mujair (Oreochromis mossambicus) pada Kondisi Sub Lethal. Jurnal Sains and Seni Pomits. 2 (2) :2337-3520

11. Robert, RJ .2001. Fish Pathology. W B Saunders. USA.

12. Wartabromo. 2015. http : // www . wartabromo.com /2015 / 09/16/7 - pabrik diinvestigasi - walhi - terkait - pencemaran - sungai - wangi / disitasi pada tanggal 1 februari 2020. 